\title{
Availability and Nutritive Value of Spirulina (Arthrospira fusiformis) from Arenguade and Chitu Lakes of Rift Valley of Ethiopia and Farmers' Perception about Its Utilization
}

\author{
Eden Getachew $^{1}$, Tegene Negesse ${ }^{2 *}$, Ajebu Nurfeta ${ }^{2}$ \\ ${ }^{1}$ College of Agriculture, Jinka University, Jinka, Ethiopia \\ ${ }^{2}$ School of Animal and Range Sciences, College of Agriculture, Hawassa University, Hawassa, Ethiopia \\ Email: edengech2015@gmail.com, *tegenengss38@gmail.com
}

How to cite this paper: Getachew, E., Negesse, T. and Nurfeta, A. (2019) Availability and Nutritive Value of Spirulina (Arthrospira fusiformis) from Arenguade and Chitu Lakes of Rift Valley of Ethiopia and Farmers' Perception about Its Utilization. Open Journal of Animal Sciences, 9, 414-428. https://doi.org/10.4236/ojas.2019.94033

Received: May 23, 2019

Accepted: September 17, 2019

Published: September 20, 2019

Copyright $\odot 2019$ by author(s) and Scientific Research Publishing Inc. This work is licensed under the Creative Commons Attribution International License (CC BY 4.0).

http://creativecommons.org/licenses/by/4.0/

\begin{abstract}
Farmers perception about availability and utilization of Spirulina (Arthrospira fusiformis) were assessed and its nutritive value compared against reference proteins (soybean and nuge cake). Samples of Spirulina were collected from Arenguade and Chitu lakes of rift valley of Ethiopia. A survey was conducted on purposively selected 100 households $(\mathrm{HH})$ living around the Lakes which are located in Gerbicha and Labu subuqa districts of Debre Zeit town and west Arsi zone, respectively. Chemical composition and in vitro dry matter digestibility (IVDMD) and total gas volume (TGV) of feed samples were determined. Respondents of both districts are not aware of Spirulina as animal feed. Spirulina was available during dry season in Arenguade and whole year in Chitu. The highest $(\mathrm{p}<0.05)$ ash $(26 \%)$, ether extract $(E E, 13 \%)$, crude protein (CP, 33\%) and IVDMD (96\%) was recorded for Spirulina from Lake Arenguade. There was no significant difference $(p>0.05)$ in crude fiber $(C F)$, neutral detergent fiber (NDF), acid detergent fiber (ADF), acid detergent lignin (ADL) and metabolizable energy (ME) contents between Spirulina from both lakes. Spirulina from Chitu produced the highest TGV $(31.2 \mathrm{ml})$ and fermented faster than Spirulina from Arenguade. Lowest $(\mathrm{p}<0.05)$ ash, EE, $\mathrm{CP}$ and IVDMD and higher $(\mathrm{p}<0.05) \mathrm{CF}, \mathrm{NDF}, \mathrm{ADF}, \mathrm{ADL}$ and TGV were recorded for reference proteins than Spirulina. ME content of Spirulina (3200 $\mathrm{kcal} / \mathrm{kg})$ was higher $(\mathrm{p}<0.05)$ than that of nuge cake $(3011 \mathrm{kcal} / \mathrm{kg})$ but lower $(\mathrm{p}<0.05)$ than that of soybean $(3474 \mathrm{kcal} / \mathrm{kg})$. Therefore, the chemical composition and IVDMD showed the potential of Spirulina to be used as a substitute of the reference feeds.
\end{abstract}




\section{Keywords}

Spirulina, Lake Arenguade, Lake Chitu, Reference Feed, Chemical Composition

\section{Introduction}

Livestock are important component of nearly all farming systems in Ethiopia and serve as source of draught power, milk, meat, manure, hides, skins and cash income. In spite of this, the productivity of livestock is low due to production constraints, socio-economic and technical limitations [1]. Inadequate feed, widespread diseases, poor breeding stock, inadequate credit, extension, marketing and infrastructure are the major constraints affecting livestock performance in the country [2], poor nutrition being the most limiting factor [3]. It was also stated that the major constraint to livestock production in developing countries is the fluctuation in quantity and quality of feeds [4]. The same authors suggested that these countries experience serious shortages of the conventional feeds. With an increasing demand for livestock products as a result of rapid growth in the world economies and shrinking land area, future hopes of feeding the millions and safeguarding their food security will depend on the better utilization of non-conventional feed resources, which cannot be used as food for humans [4]. Livestock feed cost in developing countries is a challenge. The high and increasing prices for animal feeds have compelled researchers in these countries to direct their attention to non-conventional feeds, with particular emphasis on protein substitutes [5].

The productivity of livestock and poultry in the tropics has been grossly limited by the scarcity and consequent high prices of the protein and energy sources [6]. Although soybean meal and fish meal have been widely and successfully used as reference protein sources for livestock, their prices have been escalating, whilst availability is often erratic [7]. In many developing countries animal source feed ingredients are not preferred because of high price for small scale farmers, which is a compelling reason for search of potentially useful locally available, alternative feedstuffs. The identification of new feed resources is, therefore, crucial for sustainable animal production and future viability. Ideally, the new feed resource should have high nutritive value and conversion efficiency, be able to optimize animal product quality and use land and water efficiently [8].

Thus, Spirulina has received special attention, because, these microorganisms can be a good alternative source of protein in the diet [9]. Among several microorganisms which have been studied, the blue-green algae, Spirulina, is considered a promising microorganism due to its high protein (65\% to $70 \% \mathrm{DM})$, vitamins and minerals [10] [11]. It is estimated that Spirulina can produce 125 times more protein than that of corn when grown on the same area of corn [12]. Spirulina fusiformis is a microalgae with appropriate composition to be used as a 
food supplement. It is commonly used by humans and animals as protein source. Several studies such as palatability, lack of toxicity and easy digestion, antioxidant actions, hypocholesterolemic, anticancer, immuno-stimulant, anti-inflammatory, antiviral, among others have been conducted to verify the possible benefits of Spirulina and some properties have been verified [13] [14] [15].

The addition of $1.5 \%$ to $12 \%$ of Spirulina in to the diets of broilers can replace other protein sources, especially soybean meal, with satisfactory growth rates and feed efficiency [16]. However, the optimal levels for using Spirulina as a substitute of conventional proteins in a diet are still debatable [17] [18] [19].

Algae contains proteins, carbohydrates, lipids and trace nutrients, including vitamins, antioxidants, and trace elements. The nutritional contents of algae are rapidly gaining importance as a renewable source to substitute the conventional ingredients in aquaculture/animal feed. Therefore, Spirulina is emerging as a cost effective means of improving animal productivity for a sustainable and viable food security [8].

Even though Spirulina occurs naturally in different rift valley lakes of Ethiopia there is limited information available with regard to its utilization and nutritive value. Thus this study was designed to assess availability and farmer's perception about utilization of Spirulina and compare its nutritive value (nutrient composition, in vitro dry matter degradability and gas production) against reference protein supplements (soybean and nuge cake).

\section{Materials and Methods}

\subsection{Description of the Study Area}

Lake Chitu and Arenguade were selected based on the availability of Spirulina. Lake Chitu (Figure 1) is a volcanic explosion crater lake which is located $287 \mathrm{~km}$ South of Addis Ababa in West Arsi zone, Aje district of Labu Subuqa district. Lake Chitu is situated at $25 \mathrm{~km}$ from Shashamane town with latitude $7^{\circ} 24^{\prime} 26^{\prime \prime} \mathrm{N}$,

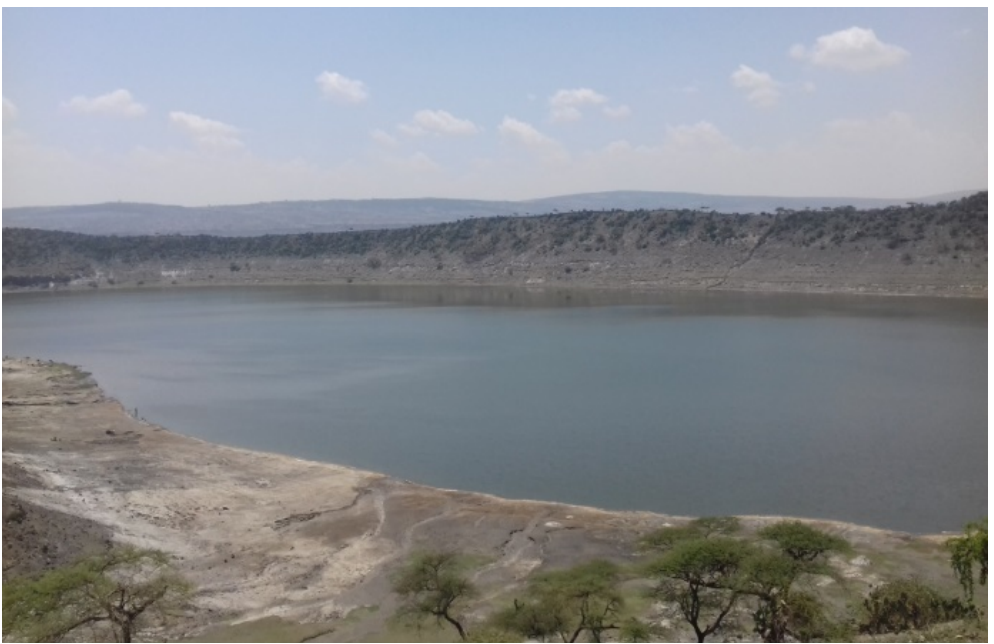

Figure 1. Lake Chitu. 
longitude of $38^{\circ} 25^{\prime} 33^{\prime \prime} \mathrm{E}$ and an altitude of 1540 meters above sea level and an area of $0.8 \mathrm{~km}^{2}$ and a maximum depth of $21 \mathrm{~m}$. It is among lakes of the National Park of the Ethiopian Rift Valley.

Lake Arenguade (Figure 2) is a member of crater lakes -Bishoftu crater lakessituated $47 \mathrm{~km}$ South East of Addis Ababa in Debre Zeit town of Gerbicha district at a latitude of $8^{\circ} 41.856^{\prime} \mathrm{N}$ and $38^{\circ} 58.796^{\prime} \mathrm{E}$ and altitude of about $1900 \mathrm{~m}$, above sea level. Lake Arenguade is an alkaline soda lake with a diameter of approximately $800 \mathrm{~m}$ and maximum and mean depth of 32 and $18 \mathrm{~m}$, respectively. Lake Arenguade is so named (Arenguade means green in Amharic language) after the green coloration of surface water by the filamentous blue-green algae.

\subsection{Sample Collection Procedure}

Samples of Spirulina were collected from Lake Arenguade and Lake Chitu from four different directions of each lake (north, south, east and west) during the months of October and April. Spirulina samples collected from different directions were used as replications for each lake. The collection was carried out by skimming the surface using a pot and draining/filtering it out. The water was let to pass through a sieve to control passage of dirt and then was further filtered by clean cloth to separate the water from spirulina. And then the sample was air dried for three days. The drying process was done inside the house (in a shade) on a concrete floor. The reference feed sources (nuge seed cake and soybean) were purchased from local market. Soybean was roasted for 5 - $10 \mathrm{~min}$ in the laboratory of Animal and Range Sciences of College of Agriculture at Hawassa University.

\subsection{Survey}

From household ( $\mathrm{HH}$ ) living in Gerbicha and Labusu buqa districts near the lake, $50 \mathrm{HH}$ were selected purposively from each district around lake Arenguade

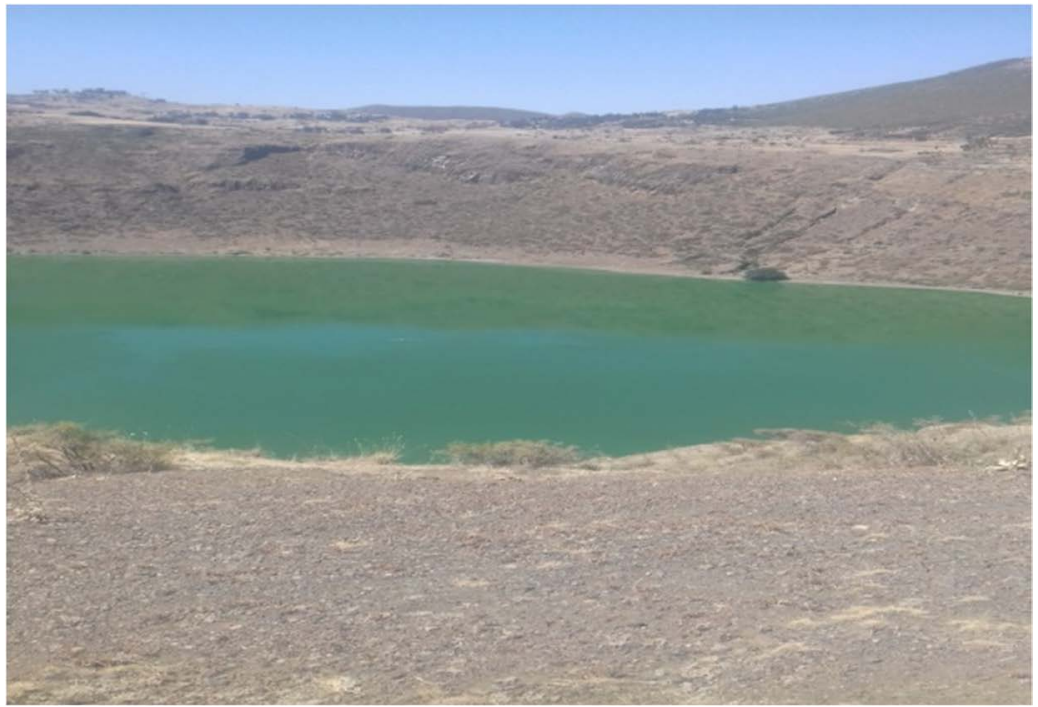

Figure 2. Lake Arenguade. 
and Chitu respectively. Around each lake, livestock owners were briefed about the objective of the study before data collection. Information about availability, farmers' awareness about Spirulina and form of utilization in the area both by humans and animals were collected using structured questioners. The interview was conducted at the residences of livestock owners with the assistance of agricultural experts or development agents.

\subsection{Chemical Analysis}

Samples of Spirulina, nuge seed cake and soybean were ground to pass through 1 $\mathrm{mm}$ sieve size. Dry matter percentage of the samples was determined by oven drying the samples at $105^{\circ} \mathrm{C}$ for 24 hours. Total ash and $\mathrm{CP}$ contents were determined [20]. Ash was determined by complete burning of the feed samples in a muffle furnace at $500^{\circ} \mathrm{C}$ overnight. Nitrogen was determined using the Kjeldhal procedure and crude protein was calculated as

$$
\mathrm{CP}=\mathrm{N} \times 6.25 \text {. }
$$

Neutral detergent fiber (NDF), acid detergent fiber (ADF) and acid detergent lignin (ADL) were analyzed using the detergent extraction method [21]. Metabolizable energy (ME) of the feed sample was calculated as:

$$
\mathrm{ME}(\mathrm{Kcal} / \mathrm{kg} \mathrm{DM})=3951+54.4 \mathrm{EE}-88.7 \mathrm{CF}-40.8 \mathrm{Ash} \quad[22] \text {. }
$$

\subsection{In Vitro Dry Matter Digestibility}

An in vitro dry matter digestibility (IVDMD) of Spirulina, nuge seed cake and soybean was determined by the method [23] which was later modified [24]. Rumen fluid was collected from three sheep which were kept at Hawassa University Animal and Range Sciences farm and were fed on medium quality diet (200 g concentrate and ad-libitum hay). The rumen fluid was collected by sucking using rumen tube before the morning feeding and placed directly into pre-warmed thermos flasks and taken immediately to the laboratory. It was then filtered through two layers of cheese cloth. About $0.5 \mathrm{~g}$ of the dried and ground samples from each feed was put in flasks containing rumen fluid-medium mixture and incubated for 48 hours at $39^{\circ} \mathrm{C}$. Microbial digestion was followed by neutral detergent refraction and the indigestible residue was measured after overnight oven drying at $105^{\circ} \mathrm{C}$.

\subsection{In Vitro Gas Production}

$200 \mathrm{mg}$ of each sample (ground to pass through a $1 \mathrm{~mm}$ sieve) were put in to 100 $\mathrm{ml}$ calibrated glass syringes in three replicates, fitted with Vaseline lubricated pistons. To prepare the inoculum, rumen fluid was collected before the morning feeding from three sheep. The rumen fluid was placed directly into pre-warmed thermos flasks and taken immediately to the laboratory. It was then filtered through two layers of cheese cloth and diluted with buffered mineral solution as previously described [25], which was maintained in a water bath at $39^{\circ} \mathrm{C}$ under 
continuous flushing with $\mathrm{CO}_{2}$. A total of $30 \mathrm{ml}$ incubation medium was transferred into glass syringes containing the samples and three blank syringes. They were then immediately placed in a temperature controlled incubator preset at $39^{\circ} \mathrm{C}$. The initial volume of each syringe was recorded before the commencement of the incubation of the samples. The gas volume was recorded after 4,8 , $12,24,48,72$ and 96 hours of incubation.

The result was fitted in to the exponential equation:

$$
p=a+b\left(1-\mathrm{e}^{-c t}\right)
$$

where $p=$ gas production at time $t, a=$ gas production from the immediately fermentable organic matter (the intercept of the gas production curve), $b=$ gas production from fermentation of the slowly but potentially fermentable organic matter, $a+b=$ potential gas production (the asymptote of the gas production curve), $c=$ rate of gas production, $t=$ incubation time, and $\mathrm{e}=$ base of natural logarithm [26] [27]. Gas production data was estimated using Neway Excel program [28].

\subsection{Statistical Analysis}

All the statistical analyses were carried out using a Statistical Package for Social Science (SPSS, version 20). The survey data was analyzed using descriptive statistics. One way independent mean comparison of parameters was used to compare data between the two study sites. Means of chemical composition, IVDMD and metabolizable energy were separated using Tukey HSD (Tukey honestly significant difference) test. The model used for chemical composition and IVDMD was:

$$
Y_{i j}=\mu+A_{i}+B_{j}+e_{i j}
$$

where $Y_{i j}=$ response variable, $\mu=$ overall mean, $A_{i}=$ variation due to lake, $B_{j}=$ variation due to sampling spot/site and $e_{i j}=$ random error effect.

\section{Results}

\subsection{General Characteristics of Sampled Households}

The majority of respondents were male and large numbers of respondents were illiterate in both study areas and very few had educational background of basic education and primary school. The age of respondents in Lake Arenguade and Chitu was $37.62 \pm 9.9$ and $38.96 \pm 8.6$ years, respectively.

The average land holding of respondents in Lake Arenguade and Lake Chitu was 1.6 and 1.8 ha, respectively. The result shows that from the total land holding, most of it was used for crop cultivation in both study areas. Their major livelihood activity in the two study sites was mixed crop livestock farming. Crop production was major source of revenue in both study areas contributing to $32 \%$ of the livelihood of the respondents. The dominant crops produced are teff, maize, wheat and barley; and they are produced once in a year. Livestock contributes to $16 \%$ of the livelihood of the lake community and is used for agricultural 
activities, income generation and sustaining family protein needs. Cattle and goat were the dominant species of livestock in the study areas followed by donkey and the least were sheep. There was greater number of livestock per households around Lake Chitu than Arenguade. The main purpose of keeping different groups of livestock species was for traction (68\% and 42\%) followed by transportation (28\% and $22 \%)$ as reported by respondents of Lake Arenguade and Lake Chitu, respectively. Few respondents keep livestock for milk and meat production, breeding and prestige.

\subsection{Feed Resources Availability and Perception of Farmers about Use of Spirulina}

As observed from the interviewees reply the availability of feed in the two study areas was similar. Crop residues such as teff straw, wheat straw and maize stover are the common and most important feed resources of livestock around both lakes followed by communal grazing land and crop aftermath. Some of the respondents supplement their livestock during feed shortage by purchasing supplementary feed. Majority of respondents indicated wet season as the season of higher feed shortage (50\% and $42 \%$ ) while less number of them said dry season (16\% and $10 \%$ of respondents) and $34 \%$ and $48 \%$ of respondents said shortage of feed is independent of season in Lake Arenguade and Chitu, respectively.

Feed shortage was the major constraint identified by respondents of the two study sites. Respondents around Lake Arenguade and Lake Chitu alleviate feed shortage by conservation of feed in the form of hay [31 (62\%) and 27 (54\%)], supplementation [16 (32\%) and $13(26 \%)]$ and destocking [3 (6\%) and 10 (20\%)], respectively

The availability of Spirulina was season dependent in Lake Arenguade where $86 \%$ of the households reported that it is available only during dry season. In Lake Chitu the majority of the respondents (92\%) stated that it is available year-round even though its biomass fluctuates between dry and wet seasons.

Spirulina was not used in both study areas as animal feed, but some of the respondents (42\%) in Lake Arenguade reported that livestock owners who live in and around Debre Zeit bring their cattle to the lake to drink the water considering it has medicinal value for animals. Almost all respondents from Lake Arenguade and Chitu indicated that cattle do not consume Spirulina. They only drink the water by removing the floating Spirulina bloom by their breath.

As reported by farmers flamingoes in Lake Arengude are rarely available and $88 \%$ of the respondents said that they had no idea if flamingoes feed on Spirulina, while the remaining 6\% of respondents said that they feed on Spirulina and others (6\%) said they feed on aquatic animals. All farmers around Lake Chitu indicated that flamingoes are there the whole year in a huge number. About 52\% of respondents around Lake Chitu alleged that the reason for a huge number of flamingoes in the lake was to feed on Spirulina while $22 \%$ of the respondents said that they feed on aquatic animals and $26 \%$ of respondents do not have any idea about what flamingoes feed on. 


\subsection{Chemical Composition, In Vitro Digestibility and Gas Production Traits}

Chemical composition and nutritive value of Spirulina from Lake Chitu and Arengude and the referenced feeds (roasted soybean and nuge cake) are shown in Table 1.

The ash content differed significantly $(\mathrm{p}<0.05)$ between Spirulina samples and much more significantly between Spirulina and the reference feeds, Spirulina having much higher ash content than the reference feeds. There was no significant difference $(\mathrm{p}>0.05)$ in the crude fiber content of Spirulina from the two lakes but their crude fiber content differs significantly $(\mathrm{p}<0.05)$ from the reference feeds. The ether extract content of Spirulina was significantly ( $\mathrm{p}<$ $0.05)$ influenced by the sampling site. As shown in Table 1 the ether extract content of Spirulina was higher than $(\mathrm{p}<0.05)$ the reference feeds. The NDF and ADF content of Spirulina from the two lakes and that of soybean did not differ ( $p>0.05$ ) but NDF and ADF content of nuge cake was higher than that of Spirulina from both lakes and soybean. There was no significant $(\mathrm{p}>0.05)$ difference in ADL value between Spirulina of the two Lakes. The ADL value of the reference feeds (roasted soybean and nuge cake) was higher $(\mathrm{p}<0.05)$ than that of Spirulina, nuge cake having the highest value. The CP content of Spirulina from Lake Arenguade was higher than that of Lake Chitu. The CP content of Spirulina was higher $(\mathrm{p}<0.05)$ than the reference feeds. Spirulina from Lake Arenguade had the highest $(\mathrm{p}<0.05)$ IVDMD followed by Spirulina from lake Chitu.

Pattern of gas production of Spirulina samples from Lake Arenguade and Chitu and the referenced feeds is given in Figure 3.

Table 1. Chemical composition and in vitro dry matter digestibility of Spirulina from Lake Arenguade and Chitu and reference feeds.

\begin{tabular}{|c|c|c|c|c|}
\hline \multirow{2}{*}{$\begin{array}{c}\text { Parameters } \\
\text { (\% DM unless specified) }\end{array}$} & \multicolumn{2}{|c|}{ Spirulina } & \multicolumn{2}{|c|}{ Reference feeds } \\
\hline & Lake Arenguade & Lake Chitu & Soybean & Nuge cake \\
\hline Dry matter (\%) & $96.42 \pm 0.06^{\mathrm{b}}$ & $96.44 \pm 0.06^{\mathrm{b}}$ & $98.46 \pm 0.13^{\mathrm{a}}$ & $98.66 \pm 0.13^{\mathrm{a}}$ \\
\hline Ash & $26.18 \pm 0.08^{\mathrm{a}}$ & $23.03 \pm 0.08^{\mathrm{b}}$ & $8.6 \pm 0.16^{\mathrm{d}}$ & $12.39 \pm 0.16^{\mathrm{c}}$ \\
\hline Crude fiber & $4.60 \pm 0.14^{\mathrm{c}}$ & $4.20 \pm 0.14^{\mathrm{c}}$ & $6.80 \pm 0.28^{b}$ & $11.50 \pm 0.28^{\mathrm{a}}$ \\
\hline Ether extract & $13.30 \pm 0.08^{\mathrm{a}}$ & $11.80 \pm 0.08^{\mathrm{b}}$ & $8.80 \pm 0.17^{\mathrm{d}}$ & $10.80 \pm 0.17^{\mathrm{c}}$ \\
\hline Neutral detergent fiber & $19.60 \pm 0.37^{\mathrm{b}}$ & $18.80 \pm 0.37^{\mathrm{b}}$ & $19.90 \pm 0.74^{\mathrm{b}}$ & $39.17 \pm 0.74^{\mathrm{a}}$ \\
\hline Acid detergent fiber & $7.02 \pm 1.01^{\mathrm{b}}$ & $6.40 \pm 1.01^{\mathrm{b}}$ & $12.60 \pm 2.03^{\mathrm{b}}$ & $23.80 \pm 2.03^{\mathrm{a}}$ \\
\hline Acid detergent lignin & $1.80 \pm 0.14^{\mathrm{c}}$ & $1.58 \pm 0.14^{\mathrm{c}}$ & $4.08 \pm 0.28^{\mathrm{b}}$ & $13.30 \pm 0.28^{\mathrm{a}}$ \\
\hline Crude protein & $33.30 \pm 0.05^{\mathrm{a}}$ & $31.30 \pm 0.05^{\mathrm{b}}$ & $29.60 \pm 0.01^{\mathrm{c}}$ & $22.20 \pm 0.01^{\mathrm{d}}$ \\
\hline $\mathrm{ME}(\mathrm{kcal} / \mathrm{kg})$ & $3203 \pm 12.6^{\mathrm{b}}$ & $3281 \pm 12.6^{\mathrm{b}}$ & $3474 \pm 25.18^{\mathrm{a}}$ & $3011 \pm 25.18^{\mathrm{c}}$ \\
\hline IVDMD (\%) & $96.67 \pm 0.18^{\mathrm{a}}$ & $95.34 \pm 0.18^{\mathrm{b}}$ & $92.67 \pm 0.36^{c}$ & $65.43 \pm 0.36^{\mathrm{d}}$ \\
\hline
\end{tabular}

$\mathrm{ME}=$ metabolizable energy; IVDMD = in vitro dry mater digestibility; means with different superscript letter across row are significantly different $(\mathrm{p}<0.05)$. 
Nuge cake fermented faster and Spirulina sample from Lake Arenguade ferments slower than soybean and Spirulina sample from Lake Chitu. There was a steady increase in gas production after $24 \mathrm{hr}$ incubation time. The cumulative gas production increased during the incubation period.

As shown in Table 2 Spirulina from Lake Chitu was fermented faster (C) than all other feeds and it was followed by roasted soybean. The highest intercept of the gas production curve (A) was in reference feeds; and the lowest in Spirulina. Spirulina from Lake Chitu had negative "A" values. Gas production from the slowly fermentable dry matter (B) was the highest in Spirulina from Lake Chitu and the lowest in Spirulina from Lake Arenguade. The potential gas production $(\mathrm{a}+\mathrm{b})$ was higher for the reference feeds than Spirulina of the two lakes; and Spirulina from Lake Chitu had higher potential gas production than that of Lake Arenguade.

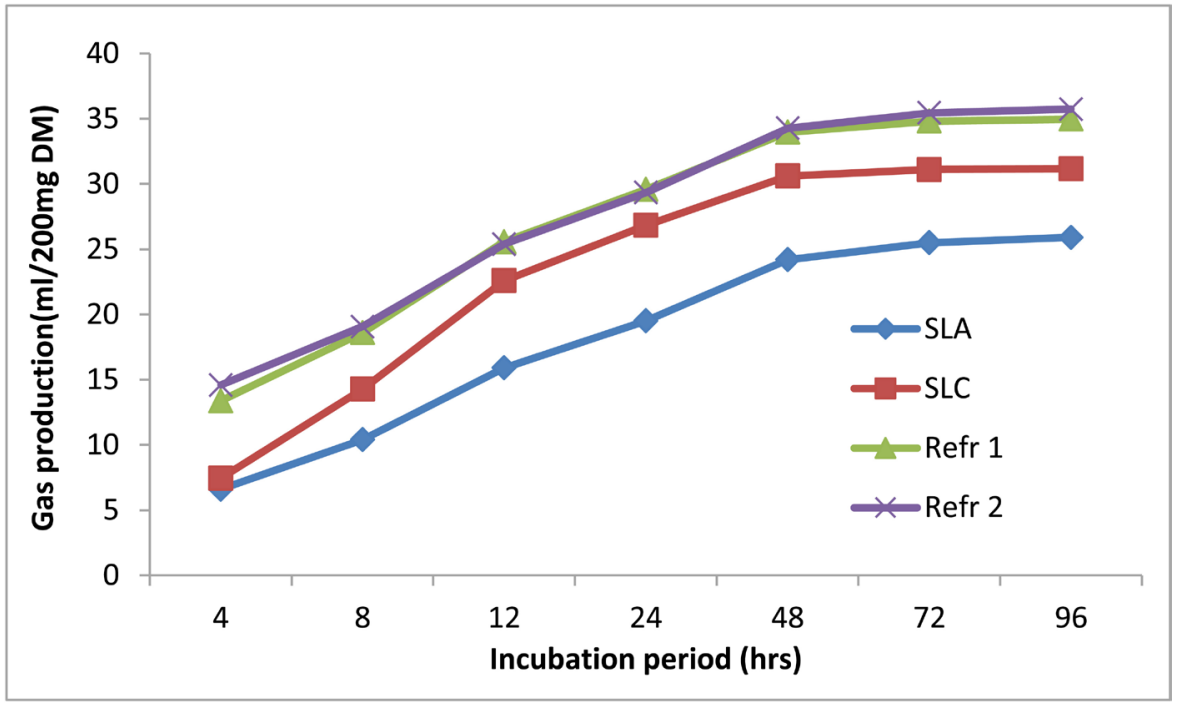

Figure 3. The pattern of fermentation of Spirulina was distinctly different from the referenced feed during the incubation time. SLA = Spirulina sample from Lake Arenguadea; SLC $=$ Spirulina sample from Lake Chitu; Refr $1=$ roasted soybean and Refr $2=$ Nuge cake.

Table 2. Gas production characteristics of Spirulina from Lake Chitu and Arenguade and reference feeds.

\begin{tabular}{ccccc}
\hline \multirow{2}{*}{ Estimated parameter } & \multicolumn{4}{c}{ Feedstuffs } \\
\cline { 2 - 5 } & Spirulina LA & Spirulina LC & Soybean & Nuge cake \\
\hline C & 0.055 & 0.085 & 0.069 & 0.059 \\
A & 1.9 & -2.1 & 6.5 & 8.9 \\
B & 24.1 & 33.3 & 28.5 & 26.9 \\
a + b & 26.0 & 31.2 & 35.0 & 35.8 \\
\hline
\end{tabular}

LA = Lake Arenguade $\mathrm{LC}=$ Lake Chitu; $\mathrm{A}=$ the gas production from the immediately soluble fraction; $\mathrm{B}=$ the gas production from the insoluble fraction; $\mathrm{C}=$ the gas production rate constant for the insoluble frac tion $\mathrm{b}(\mathrm{h}) ; \mathrm{a}+\mathrm{b}=$ potential gas production. 


\section{Discussion}

The average land holding in both the study areas is lower than those reported for other studies [29] [30] possibly due to differences in population density of the areas. The livelihood of respondents in both the study areas is mainly based on agriculture and it is of mixed crop livestock production system. This result is in line with earlier reports that mixed agriculture is the major livelihood activity (72.5\%) of people living around Chitu Lake and the contribution of livestock in supporting the livelihood of lake community is of paramount importance [31]. Respondents of both lake communities keep mixture of livestock species for different reasons [32]. Feed shortage was the major livestock production constraint in both the study areas, crop residues being the main feed resource throughout the year. This result agrees with earlier report that natural pasture and crop residues are the major feed resources of Ethiopia [33]. The livestock production constraints reported in this study are in agreement with the observations that inadequate feed and nutrition, poor health, low productivity of local breeding stock are the main livestock production constraints in Ethiopia [2].

Communities around both lakes were not feeding Spirulina to their animals even though it is available in both lakes. Respondents from around Lake Arenguade believe that lake water has medicinal value for animals which agrees with earlier report where local people were encouraging their cattle to drink lake water believing that the Spirulina water has some therapeutic effects and compensates for some deficiency in diets of cows [34] [35].

The ether extract (EE) content of Spirulina was higher than that of the reference feeds $(11 \%-13 \%)$. It has been reported earlier that the EE content of Spirulina ranges from $5.6 \%$ to $7 \%$ [36] [37] and from $6 \%$ to $13 \%$ [38] [39]. As can be seen most of EE values earlier reported are lower than the findings in this study. The crude fiber content of Spirulina from both lakes was lower than that of the reference feeds. It was revealed that the fiber content in Spirulina varied from $4 \%$ to $7 \%$; the results of the present study fall within this range, but very close to the lower range [40]. However, crude fiber content in $S$. platensis was reported as $0.5 \%$ which is extremely lower than the values obtained in this study [41]; and a fiber content of Spirulina ranging from $8 \%$ to $10 \%$ was also reported which is again much higher than the values in this study [42]. The ash content of Spirulina in this study was higher than that of the reference feeds. The ash content from the current study was much higher than the values $(6.4 \%-9 \%, 7 \%$ and 8.41\%) earlier reported [37] [43] [44] [45]; respectively. This might be due to the difference in geographical location of the sample. Many factors may affect the bioaccumulation of minerals in Spirulina and the most important ones were differences in culture media, temperatures, $\mathrm{pH}$ and salinity [42]. Crude protein content of Spirulina was reported as 58.2\% [46]. Also higher CP content (69.2\%) was also obtained [45] in Spirulina from Kanem Lake Chad. The differences could be explained by differences in either the environment, or climate, or the techniques used to collect $S$. platensis [47]. Metabolizable energy content of Spi- 
rulina in the current study is similar with literature results ( 2500 to $3290 \mathrm{kcal} / \mathrm{kg}$ ) reported [48] [49] [50].

The IVDMD of Spirulina was higher than the reference feeds which may be due to the higher level of fiber in the reference feeds when compared to Spirulina which agrees with earlier results reported and the decrease in IVDMD may be associated with its high lignin content as feeds with less lignin promote better access to microorganisms [51]. Furthermore, Spirulina cell walls are mucopolysaccharides (complex sugars) that are easily digestible. Digestibility tests have shown Spirulina to be $83 \%$ to $95 \%$ digestible [52].

In the current study, the gas production of Spirulina was lower than the reference feeds throughout the incubation period which may be due to higher $\mathrm{CP}$ content of Spirulina. Even though gas production (A and B) of the reference feeds was higher than Spirulina the potential gas production of the reference feed was lower. This result is in line with earlier reports that stated the potential of gas production $(a+b)$ for protein feed source was lower than that of carbonaceous concentrate feedstuffs [53]. It was also reported that protein fermentation does not lead to extensive gas production [54]. Besides, the lower gas volume of Spirulina might be further clarified by the presence of high fat, which contributes to negligible gas production [55].

\section{Conclusion}

Spirulina samples collected from Lake Chitu and Lake Arenguade differ in their ash, ether extract, crude protein, IVDMD and TGV. Spirulina has a comparable DM and ME but lower fiber and TGV and higher ash, EE, CP and IVDMD than the reference feeds (soybean and nuge cake). Spirulina is thus better than the reference feeds and can be used as a substitute for the reference protein supplements in animal feed because it is available most of the time in both lakes and can also minimize feed cost. Results of this study indicated feed shortage as the major livestock production constraint in both study areas and crop residues as the major feed resources available are low in quality to meet the requirement of livestock and thus Spirulina can partly offset the shortage. Respondents of both lake communities are not feeding Spirulina to animals; therefore, the use of Spirulina in animal feed should be encouraged through awareness creation to improve livestock production and productivity in the study areas. Further researches of the effect of feeding Spirulina on animal performance are suggested.

\section{Conflicts of Interest}

The authors declare no conflicts of interest regarding the publication of this paper.

\section{References}

[1] Mengistu, A. (2003) Country Pasture/Forage Resources Profiles: Ethiopia. Food and Agriculture Organization of the United Nations (FAO), Rome. 
[2] Desta, L., Kassie, M., Benins, S. and Pender, J. (2000) Land Degradation and Strategies for Sustainable Development in Ethiopian Highlands: Amhara Region. ILRI Socioeconomics and Policy Research Working Paper 32. International Livestock Research Institute (ILRI), Nairobi, 122.

[3] Tadesse, A. (1998) The Unexploited Potential of Improved Forages in the Mid Altitude and Low Land Areas of Ethiopia. PANES/ ANRAB (Pasture Network for Eastern and Southern Africal African Research Network for Agricultural By-Products) Utilization of Research Results on Forage and Agricultural By-Products of the First Joint Workshop, Lilongwe, 5-9 December 1988, 503-517.

[4] Makkar, H.P.S. and Becker, K. (1998) Do Tannins in Leaves of Trees and Shrubs from Africa and Himalayan Regions Differ in Level and Activity? Agro Forestry Systems, 40, 59-68. https://doi.org/10.1023/A:1006027231497

[5] Gaia, S. (2005) Wondertree-100 Facts-Moringa Fact 04-Exceptional Animal Feed: Moringa as Livestock Feed \& Pet Food. Moringa Mission Trust.

http://gaiathelivingplanet.blogspot.com/2005/06/wondertree-100-facts-moringa-fac t-04.html

[6] Melesse, A., Tiruneh, W. and Negesse, T. (2011) Effects of Feeding Moringa stenopetala Leaf Meal on Nutrient Intake and Growth Performance of Rhode Island Red Chicks under Tropical Climate. Tropical and Subtropical Agroecosystems, 14, 485-492.

[7] Nuhu, F. (2010) Effect of Moringa Leaf Meal (MOLM) on Nutrient Digestibility, Growth, Carcass and Blood Indices of Weaner Rabbits. Master of Science Thesis in Animal Nutrition, Kwame Nkurumah University of Science and Technology, Kumasi.

[8] Poppi, D.P. and McLennan, S.R. (2010) Nutritional Research to Meet Future Challenges. Animal Production Science, 50, 329-338. https://doi.org/10.1071/AN09230

[9] Rogatto, G.P., Oliveira, C.A.M. and Santos, J.W. (2004) Influência da ingestão de e Spirulina sobre o metabolismo de ratosexercitados. Revista Brasileira de Medicinado Esporte, 10, 258-263. https://doi.org/10.1590/S1517-86922004000400003

[10] Contreras, A., Herbert, D.C. and Grubbs, B.G. (1979) Blue-Green Alga, Spirulina, as the Sole Dietary Source of Protein in Sexually Maturing Rats. Nutrition Reports International, 19, 749-763.

[11] Kay, R.A. (1991) Microalgae as Food and Supplement. Food Science and Nutrition, 30, 555-573. https://doi.org/10.1080/10408399109527556

[12] Furst, P.T. (1978) Spirulina a Nutricious Alga, Once a Staple of Aztec Diet, Could Feed Many of the World Hungry People. Human Nature, 3, 60.

[13] Rodriguez-Hernandez, A., Blé-Castillo, J.L. and Juárez-Oropeza, M.A. (2001) Spirulina Maxima Prevents Fatty Liver Formation in CD-1 Male and Female Mice with Experimental Diabetes. Life Sciences, 69, 1029-1037. https://doi.org/10.1016/S0024-3205(01)01185-7

[14] Derner, R.B., Ohse, S. and Villela, M. (2006) Microalgas, produtos e aplicações. Ciência Rural, 36, 1959-1967. https://doi.org/10.1590/S0103-84782006000600050

[15] Colla, L.M., Furlong, E.B. and Costa, J.A.V. (2007) Antioxidant Properties of Spirulina (Arthrospira platensis) Cultivated under Different Temperatures and Nitrogen Regimes. Brazilian Archives of Biology and Technology, 50, 161-167. https://doi.org/10.1590/S1516-89132007000100020

[16] Ross, E. and Dominy, W. (1990) The Nutritional Value of Dehydrated Blue-Green Algae (Spirulina Platensis) for Poultry. Poultry Science, 69, 794-800.

https://doi.org/10.3382/ps.0690794 
[17] Soler, A., Valdivié, M. and Dieppa, O. (2000) Usode la Spirulina comopigmentante de la piel y la grasa de lospollos de ceba. Revista de la Facultad de Ciencias Veterinárias, 41, 19-24

[18] Lacaz-Ruiz, R. (2003) Spirulina: Estudos e trabalhos. Roca, São Paulo, 296.

[19] Becker, B.W. (2007) Micro-Algae as a Source of Protein. Biotechnology Advances, 25, 207-210. https://doi.org/10.1016/j.biotechadv.2006.11.002

[20] AOAC (Association of Official Analytical Chemists) (1990) Official Methods of Analysis. 13th Edition, AOAC Arlington, Verginia, 12-98.

[21] Van Soest, P.J., Robertson, J.B. and Lewis, B.A. (1991) Methods for Dietary Fiber, Neutral Detergent Fiber and Non-Starch Carbohydrates in Relation to Animal Nutrition. Journal of Dairy Science, 74, 3583-359. https://doi.org/10.3168/jds.S0022-0302(91)78551-2

[22] Wiseman, J. (1987) Feeding of Non-Ruminant Livestock. Butterworth and Co. Ltd., London, 9-15.

[23] Tilley, J.M.A. and Terry, R.A. (1963) A Two-Stage Technique for the in Vitro Digestion of Forage Crops. Journal of the British Grassland Society, 18, 104-111. https://doi.org/10.1111/j.1365-2494.1963.tb00335.x

[24] Van Soest, P.J. and Robertson, J.B. (1985) Analysis of Forages and Fibrous Foods: A Laboratory Manual for Animal Science 613. Cornell University, Ithaca, New York, 202.

[25] Menke, K.H., Raab, L., Salewski, A., Steingass, H., Fritz, D. and Schneider, W. (1979) The Estimation of the Digestibility and Metabolizable Energy Content of Ruminant Feedstuffs from the Gas Production When They Are Incubated with Rumen Liquor in Vitro. The Journal of Agricultural Science, 93, 217-222. https://doi.org/10.1017/S0021859600086305

[26] Ørskov, E.R. and McDonald, I. (1979) The Estimation of Protein Degradability in the Rumen from Incubation Measurements Weighted According to Rate of Passage. Journal of Agricultural Science, 92, 499-503. https://doi.org/10.1017/S0021859600063048

[27] Blümmel, M. and Ørskov, E.R. (1993) Comparison of in Vitro Gas Production and Nylon Bag Degradability of Roughages in Predicting Feed Intake in Cattle. Animal Feed Science and Technology, 40, 109-119. https://doi.org/10.1016/0377-8401(93)90150-I

[28] Chen, X.B. (1997) Neway Excel: A Utility for Processing Data of Feed Degradability and in Vitro Gas Production (Version 5.0). Rowett Research Institute, Aberdeen.

[29] Keba, F. (2009) Sheep Production System in Damot Gale Woreda and Supplementary Value of Pigeon Pea (Cajanus cajan) and Sweet Potato (Ipomoea batatus) in Sheep Fattening Diets. Msc. Thesis, Hawassa University, Awassa.

[30] Assefa, E. (2007) Assessment on Production System and Marketing of Goats at Dale District (Sidama Zone). MSc Thesis, University of Hawassa, Hawassa.

[31] Faris, G. and Tefera, G. (2017) Threats, Use and Management Interventions for Restoration of Lake Chitu West Arsi, Ethiopia. American Journal of Biological and Environmental Statistics, 3, 1-4. https://doi.org/10.11648/j.ajbes.20170301.11

[32] Alemayehu, N., Gebru, G. and Drucker, A. (2004) Mobility, Herd Dynamics and Species Composition of Pastoralists, Indigenous Innovations towards Copping $\mathrm{Me}-$ chanism during Crisis. Participatory Innovation and Research, Lessons for Livestock Development. Proceedings of the 12 th Annual Conference of Ethiopia Society of Animal Production, Addis Ababa, 12-14 August 2004, 77-86. 
[33] Tolera, A., Yami, A. and Alemu, D. (2012) Livestock Feed Resources in Ethiopia: Challenges, Opportunities and the Need for Transformation. Ethiopia Animal Feed Industry Association, Addis Ababa.

[34] Kebede, E. (1997) Response of Spirulina platensis (Arthrospira Fusiformis) from Lake Chitu, Ethiopia, to Salinity Stress from Sodium Salts. Journal of Applied Phycology, 9, 551-558. https://doi.org/10.1023/A:1007949021786

[35] Klemperer, S.L. and Cash, M.D. (2007) Temporal Geochemical Variation in Ethiopian Lakes Shala, Arenguade, Awasa, and Beseka: Possible Environmental Impacts from Underwater and Borehole Detonations. Journal of African Earth Sciences, 48, 174-198. https://doi.org/10.1016/j.jafrearsci.2006.10.006

[36] Earthrise, I. (1986) Product Typical Analysis. Earthrise Farms Spirulina San Raphael, USA. In: Charply, L., Ed., International Symposium on Cyanobacteria for Health, Science and Development, 104-108.

[37] Fox, R.D. (1996) Spirulina: Production and Potential. EDISUD, Aix-en-Provence, $232 \mathrm{p}$.

[38] Cohen, Z. (1997) Chemical from Spirulina in Spirulina platensis. Physiology, Cell-Biology and Biotechnology. Taylor \& Francis Ltd., Abingdon-on-Thames.

[39] Xue, H., Hu, Q., Saito, H., Zhang, H., Li, J., Cai, P., Ou, R., Lin, H. and Imbs, B. (2002) Molecular Species Composition of Glycolipids from Spirulina platensis. Food Chemistry, 77, 9-13. https://doi.org/10.1016/S0308-8146(01)00315-6

[40] Albert, N., Wague, R., Mbaïlao, M. and Fabienne, N. (2012) Changes in the Physico-Chemical Properties of $S$. platensis from Three Production Sites in Chad. Journal of Animal and Plant sciences, 13, 1811-1822. http://www.m.elewa.org/JAPS/2012/13.3/4.pdf

[41] Moreira, M., Ribeiro, C., Duarte, A., Michele, G. and Leonor, S. (2013) Spirulina platensis Biomass Cultivated in Southern Brazil as a Source of Essential Minerals and Other Nutrients. African Journal of Food Science, 7, 451-455. https://doi.org/10.5897/AJFS2013.1082

[42] Habib, M.A.B., Parvin, M., Huntington, T.C. and Hasan, M.R. (2008) A Review on Culture, Production and Use of Spirulina as Food for Humans and Feeds for Domestic Animals and Fish, FAO Fisheries and Aquaculture Circular. Food and Agriculture Organization of the United Nations, Rome, 1-26.

[43] Henrickson, R. (1997) Earth Food. How Remarkable Blue Green Algae Can Transform Your Health and Our Planet. Ronores Enterprises, Kenfood, 317 p.

[44] Flamant Vert (1988) Producing spirulina in Autonomous Systems. In: Jourdan, J.P., Ed., Artisanal Culture Manual for de spirulina Production, Antenna Technology, $146 \mathrm{p}$.

[45] Mbaïguinam, M., Tarkodjiel, M. and Maoura, N. (2006) Culture and Comparison Study of the Chemical Composition of Blue Algae of Kanem-Lake (Spirulina platensis). Annual University NDjamena, C Series, Exact and Applied Sciences and Health, 1, 10-21.

[46] Alvarenga, R., Rodrigues, B., Cantarelli, S., Zangeronimo, G., Júnior, S., Silva, R., Santos, M. and Pereira, J. (2011) Energy Values and Chemical Composition of Spirulina (Spirulina platensis) Evaluated with Broilers. Revista Brasileira de Zootecnia, 40, 992-996. https://doi.org/10.1590/S1516-35982011000500008

[47] Clement, G. (1975) Production et constituants caractéristiques des algues Spirulina platensis et maxima. Annales de la Nutrition et de P Alimentation, 29, 447-488.

[48] Blum, K., Wallace, J.E., Schwertner, H.A. and Eubanks, J.D. (1976) Enhancement of 
Ethanol-Induced Withdrawal Convulsions by Blockade of 5-Hydroxytryatamine Receptors. Journal of Pharmacy and Pharmacology, 28, 832-835. https://doi.org/10.1111/j.2042-7158.1976.tb04066.x

[49] Yoshida, M. and Hoshi, H. (1980) Nutritive Value of Spirulina, Green Algae for Poultry. Japan Poultry Science, 17, 27-30. https://doi.org/10.2141/jpsa.17.27

[50] Bras, R. (2011) Energy Values and Chemical Composition of Spirulina (Spirulina platensis) Evaluated with Broilers. Revista Brasileira de Zootecnia, 40, 992-996. https://doi.org/10.1590/S1516-35982011000500008

[51] Goes, R.H.B.T., Souza, K.A., Patussi, R.A., Cornelio, T.C., Oliveira, E.R. and Brabes, K.C.S. (2010) Degradabilidade in Situ dos grãos de crambe, girassol e soja, e de seus coprodutos em ovinos. Acta Scientiarum: Animal Sciences, 32, 271-277. https://doi.org/10.4025/actascianimsci.v32i3.7913

[52] Tefera, G. (2009) Spirulina: The Magic Food. Microbial Genetic Resources Department, Institute of Biodiversity Conservation, Addis Ababa.

[53] Chumpawadee, S., Sommart, K., Vongpralub, T. and Pattarajinda, V. (2005) Nutritional Evaluation of Energy Feed Source for Ruminant Using in Vitro Gas Production Technique. Suranaree Journal of Sciences and Technology, 12, 239-247. https://doi.org/10.3923/pjn.2005.298.303

[54] Khazaal, K., Dentinho, M.T., Ribeiro, J.M. and Ørskov, E.R. (1995) Prediction of Apparent Digestibility and Voluntary Feed Intake of Hays Fed to Sheep: Comparison between Fiber Component, in Vitro Digestibility or Characteristics of Gas Production or Nylon Bag Degradation. Animal Science, 61, 521-538. https://doi.org/10.1017/S1357729800014107

[55] Abera, M., Bulang, M. and Kluth, H. (2009) Evaluating the Nutritive Values and in Vitro Degradability Characteristics of Leaves, Seeds and Seedpods from M. stenopetala. Journal of Science and Food Agriculture, 89, 281-287.

https://doi.org/10.1002/jsfa.3439 